\title{
Shewanella surugensis sp. nov., Shewanella kaireitica sp. nov. and Shewanella abyssi sp. nov., isolated from deep-sea sediments of Suruga Bay, Japan
}

\author{
Masayuki Miyazaki, ${ }^{1}$ Yuichi Nogi, ${ }^{1}$ Ron Usami ${ }^{2}$ and Koki Horikoshi ${ }^{1}$ \\ ${ }^{1}$ Extremobiosphere Research Center, Japan Agency for Marine-Earth Science and Technology \\ (JAMSTEC), 2-15 Natsushima-cho, Yokosuka 237-0061, Japan \\ ${ }^{2}$ Faculty of Engineering, Toyo University, 2100 Kuzirai, Kawagoe 350-8585, Japan
}

\begin{abstract}
Six strains representing three novel species were isolated from deep-sea sediment in Suruga Bay, Japan, at a depth of 2406-2409 m. On the basis of 16S rRNA gene sequence analysis, the isolated strains, $c 931^{\top}, c 941^{\top}, d 943, c 952, d 954$ and $c 959^{\top}$, are closely affiliated with members of the genus Shewanella. The hybridization values for DNA-DNA relatedness between these strains and Shewanella reference strains were significantly lower than that which is accepted as the phylogenetic definition of a species. On the basis of their distinct taxonomic characteristics, the isolated strains represent three novel Shewanella species, for which the names Shewanella kaireitica sp. nov. (three strains, type strain $\mathrm{c} 931^{\top}=\mathrm{JCM} 11836^{\top}=\mathrm{DSM} 17170^{\top}$ ),

Shewanella abyssi sp. nov. (two strains, type strain $\left.\mathrm{c} 941^{\top}=\mathrm{JCM} 13041^{\top}=\mathrm{DSM} 17171^{\top}\right)$ and Shewanella surugensis sp. nov. (type strain $c 959^{\top}=\mathrm{JCM} 11835^{\top}=\mathrm{DSM} 17177^{\top}$ ) are proposed.
\end{abstract}

The genus Shewanella comprises Gram-negative, facultatively anaerobic gammaproteobacteria (MacDonell \& Colwell, 1985) and is typical of deep-sea bacterial genera (DeLong et al., 1997). The genus includes psychrophilic and mesophilic species that are widely distributed in nature, especially in aquatic environments such as freshwater and the ocean (Semple \& Westlake, 1987; Myers \& Nealson, 1988; Simidu et al., 1990; Gauthier et al., 1995; Bowman et al., 1997; Makemson et al., 1997; Nogi et al., 1998; Venkateswaran et al., 1999; Ivanova et al., 2001, 2004; Satomi et al., 2003; Hirota et al., 2005). To date, at least 31 Shewanella species have been recognized. The genus Shewanella is divided into two subgenera on the basis of phylogenetic structure, growth properties in relation to pressure and polyunsaturated fatty acid production (Kato \& Nogi, 2001). In this paper, we describe the results of taxonomic studies on six strains isolated from Suruga Bay, Japan. Several lines of evidence indicate that these isolates represent three novel species within the genus Shewanella.

Strains $\mathrm{c} 931^{\mathrm{T}}, \mathrm{c} 941^{\mathrm{T}}, \mathrm{d} 943, \mathrm{c} 952, \mathrm{~d} 954$ and $\mathrm{c} 959^{\mathrm{T}}$ were isolated at a depth of 2406-2409 $\mathrm{m}$ from a deep-sea sediment, using sterilized mud samplers on the unmanned submersible Kaiko positioned off Matsuzaki in Suruga Bay (34

The GenBank/EMBL/DDBJ accession numbers for the $16 \mathrm{~S}$ rRNA and gyrB gene sequences determined in this study are AB094597, AB094598, AB201475 and AB201780-AB201788, as detailed in Fig. 1. $\left.36 \cdot 55^{\prime} \mathrm{N} 138^{\circ} 34 \cdot 77^{\prime} \mathrm{E}\right)$. The following reference strains were used. Shewanella benthica ATCC $43992^{\mathrm{T}}$ and Shewanella pealeana ATCC $700345^{\mathrm{T}}$ were obtained from the American Type Culture Collection (Manassas, VA, USA), Shewanella marinintestina JCM $11558^{\mathrm{T}}$, Shewanella sairae JCM $11563^{\mathrm{T}}$ and Shewanella schlegeliana JCM $11561^{\mathrm{T}}$ were obtained from the Japan Collection of Microorganisms (Wako, Japan) and Shewanella gelidimarina ACAM $456^{\mathrm{T}}$ was obtained from the Australian Collection of Antarctic Micro-organisms (Hobart, Tasmania, Australia). Shewanella pneumatophori SCRC- $2738^{\mathrm{T}}$ was obtained from Dr Kikue Hirota (Research Institute of Genome-based Biofactory, National Institute of Advanced Industrial Science and Technology, Sapporo, Japan). Shewanella violacea $\mathrm{DSS} 12^{\mathrm{T}}$ was from our laboratory stock. These bacteria were incubated on marine agar 2216 (Difco). Agar plates were incubated aerobically for $2-3$ days at the optimum temperature. Unless indicated otherwise, physiological tests were performed with a slight modification (use of artificial seawater; $1 \times$ artificial seawater consists of $3 \% \mathrm{NaCl}, 0.07 \% \mathrm{KCl}, 1.08 \% \mathrm{MgCl}_{2} .6 \mathrm{H}_{2} \mathrm{O}, 0.54 \%$ $\left.\mathrm{MgSO}_{4} .7 \mathrm{H}_{2} \mathrm{O}, 0 \cdot 1 \% \mathrm{CaCl}_{2} .2 \mathrm{H}_{2} \mathrm{O}\right)$ of the general procedures described by Barrow \& Feltham (1993) and Baumann et al. (1972). Optimal temperatures for growth were determined on the basis of optical density in marine broth 2216 (Difco). Acid production from sugars was assessed using modified OF medium (Hugh \& Leifson 1953) containing $0.5 \times$ artificial seawater, $0.05 \%\left(\mathrm{NH}_{4}\right)_{2} \mathrm{SO}_{4}, 0.01 \%$ yeast extract (Difco), $0.05 \%$ Tris base, $0.5 \%$ agar, $0.003 \%$ 
bromothymol blue and $1 \%$ test sugar $(\mathrm{pH}$ was adjusted to $7 \cdot 1$ at $20{ }^{\circ} \mathrm{C}$ ), with incubation at the optimum temperature. Salt-tolerance tests were performed using medium containing $0.5 \%$ Pepton (Difco), $0.5 \%$ yeast extract, $0.32 \%$ $\mathrm{MgSO}_{4} \cdot 7 \mathrm{H}_{2} \mathrm{O}$ and $0 \cdot 1 \% \mathrm{~K}_{2} \mathrm{HPO}_{4}$, with $\mathrm{NaCl}$ concentrations of $0-15 \%(\mathrm{w} / \mathrm{v})$.

Cellular fatty acids were extracted and analysed as described by Komagata \& Suzuki (1987). Isolated strains were cultured in marine broth 2216 medium at optimal temperatures. Cells were washed twice with $0.7 \% \mathrm{NaCl}$ at $4{ }^{\circ} \mathrm{C}$; this was followed by centrifugation at $8000 \mathrm{~g}$ and freeze-drying. Dried cells $(20 \mathrm{mg})$ were placed in Teflon-lined, screwcapped tubes containing $2 \mathrm{ml}$ anhydrous methanolic $\mathrm{HCl}$ and heated to $100{ }^{\circ} \mathrm{C}$ for $3 \mathrm{~h}$. After cooling, $1 \mathrm{ml}$ water was added and the fatty acid methyl esters were extracted with n-hexane. Samples were analysed using a Shimadzu model GCMS-QP5050A gas-liquid chromatograph/mass spectrometer with a DB-5MS column (J\&W Scientific). Isoprenoid quinones were extracted with chloroform/methanol $(2: 1)$ from dried cells $(200 \mathrm{mg}$ ) and purified using TLC. The purified isoprenoid quinones were analysed using reversedphase HPLC (Komagata \& Suzuki, 1987).

Chromosomal DNA was purified by using a standard method (Saito \& Miura, 1963). The DNA G + C content was determined using reversed-phase HPLC (Tamaoka \& Komagata, 1984). For analysis of relatedness, DNA-DNA hybridization was carried out at $40{ }^{\circ} \mathrm{C}$ for $4 \mathrm{~h}$ and measured fluorometrically using the method of Ezaki et al. (1989).

$16 \mathrm{~S}$ rRNA and gyrB gene sequences were obtained by direct sequencing of PCR-amplified DNA as described previously (Kato et al., 1998; Yamamoto \& Harayama, 1995). Nucleotide substitution rates $\left(K_{\text {nuc }}\right)$ (Kimura, 1980) were determined and a distance matrix tree was constructed with the neighbour-joining method (Saitou \& Nei, 1987), using the CLUSTAL X program (Thompson et al., 1997). Alignment gaps and unidentified base positions were not taken into consideration in the calculations. The topology of the phylogenetic tree was evaluated by performing bootstrap analysis with 1000 replicates. The GenBank/DDBJ/EMBL accession numbers for the 16S rRNA and gyrB gene sequences of the isolates are shown in Fig. 1; reference sequences were obtained from the GenBank database.

Morphological, cultural, physiological and biochemical characteristics of the isolates are shown in Table 1 or given in the species descriptions below. The cells of the novel deep-sea strains were Gram-negative rods that were motile by means of single, unsheathed, polar flagella. These strains were facultatively anaerobic chemo-organotrophs, displaying both respiratory and fermentative types of metabolism. All of the isolates were able to grow in $1-5 \% \mathrm{NaCl}$ but not in the absence of $\mathrm{NaCl}$, and the optimal concentration for growth was $2-3 \% \mathrm{NaCl}$.

Phenotypic analysis segregated the strains into three groups, (i) strains $c 931^{\mathrm{T}}, \mathrm{c952}$ and c954, (ii) strains $\mathrm{c} 941^{\mathrm{T}}$ and $\mathrm{d} 943$ and (iii) strain $\mathrm{c} 959^{\mathrm{T}}$, with the following properties. (i) Strains $\mathrm{c} 931^{\mathrm{T}}, \mathrm{c} 952$ and $\mathrm{c} 954$ grew at $2-28^{\circ} \mathrm{C}$, with an optimum at $24-25^{\circ} \mathrm{C}$. Strains $\mathrm{c} 931^{\mathrm{T}}$ and c952 (but not strain c954) were able to grow in $7 \% \mathrm{NaCl}$. Tween 80 and chitin were hydrolysed. Acid, but not gas, was produced from cellobiose, D-fructose, D-galactose, D-glucose, maltose and D-sorbitol. The $\mathrm{G}+\mathrm{C}$ content of the DNA was $43 \cdot 0$ $44 \cdot 3 \mathrm{~mol} \%$. The major isoprenoid quinones were Q-7 (70-80\%) and Q-8 (20-30\%). (ii) Strain $c 941^{\mathrm{T}}$ exhibited growth at $2-18^{\circ} \mathrm{C}$, with an optimum at $10^{\circ} \mathrm{C}$, and strain d943 grew at $2-24^{\circ} \mathrm{C}$, with an optimum at $14^{\circ} \mathrm{C}$. Strains c941 ${ }^{\mathrm{T}}$ and d943 did not hydrolyse Tween 80 and strain c941 ${ }^{\mathrm{T}}$ utilized cellobiose. The $\mathrm{G}+\mathrm{C}$ content of the DNA was $43 \cdot 5-43 \cdot 6 \mathrm{~mol} \%$. The major isoprenoid quinones were Q-7 $(65-70 \%)$ and Q-8 (30-35\%). (iii) Strain c959 ${ }^{\mathrm{T}}$ exhibited growth at $2-21^{\circ} \mathrm{C}$, with an optimum at $13{ }^{\circ} \mathrm{C}$. No growth occurred at temperatures above $25^{\circ} \mathrm{C}$. Tests for cytochrome oxidase, $\mathrm{H}_{2} \mathrm{~S}$ production and reduction of nitrite to nitrogen were negative. Acid, but not gas, was produced from D-fructose, D-glucose, glycerol, D-mannose and sucrose. The $\mathrm{G}+\mathrm{C}$ content of the DNA was $40 \cdot 0 \mathrm{~mol} \%$. The major isoprenoid quinones were Q-7 (5\%) and Q-8 (95\%).

The results of the phylogenetic analyses using $16 \mathrm{~S}$ rRNA and $g y r B$ gene sequences are shown in Fig. 1. These results support the conclusions described below and further clarify the taxonomic and phylogenetic positions of the novel isolates among members of the genus Shewanella and related genera. Strains $\mathrm{c} 931^{\mathrm{T}}$, d954 and $\mathrm{c} 952$ were most closely related to $S$. schlegeliana $(98 \cdot 6-98 \cdot 8 \%$ similarity for $16 \mathrm{~S}$ rRNA, $86 \cdot 0-86 \cdot 5 \%$ similarity for $g y r B)$, strains c $941^{\mathrm{T}}$ and $\mathrm{d} 943$ were most closely related to S. gelidimarina

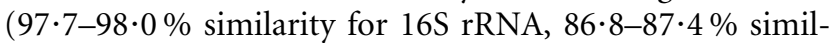
arity for $g y r B$ ) and strain $c 959^{\mathrm{T}}$ was most closely related to $S$. gelidimarina $(97 \cdot 1 \%$ similarity for $16 \mathrm{~S}$ rRNA), but showed less than $80 \%$ gyrB gene sequence similarity to Shewanella species. The generally recommended and accepted criteria for delineating bacterial species state that strains with $16 \mathrm{~S}$ rRNA gene sequence dissimilarity greater than $3 \%$ are considered to belong to separate species (Stackebrandt \& Goebel, 1994; Stackebrandt et al., 2002); within the genus Shewanella, strains with gyrB gene sequence dissimilarity greater than $10 \%$ are considered to belong to separate species (Venkateswaran et al., 1999). However, bacterial strains with gyrB gene sequences that differ by less than $10 \%$ cannot be allocated to the same species without support from DNA-DNA relatedness studies. The generally recognized criteria for delineating bacterial species state that strains with a DNA-DNA relatedness of less than $70 \%$, as measured by hybridization, represent separate species (Wayne et al., 1987).

The results of DNA-DNA hybridization analysis indicated that the novel isolates fell into three groups (Table 2), the same grouping revealed by phenotypic characteristics and phylogenetic analyses. There was more than $70 \%$ DNA relatedness among the strains in each group, and each group was clearly separate, representing distinct species 


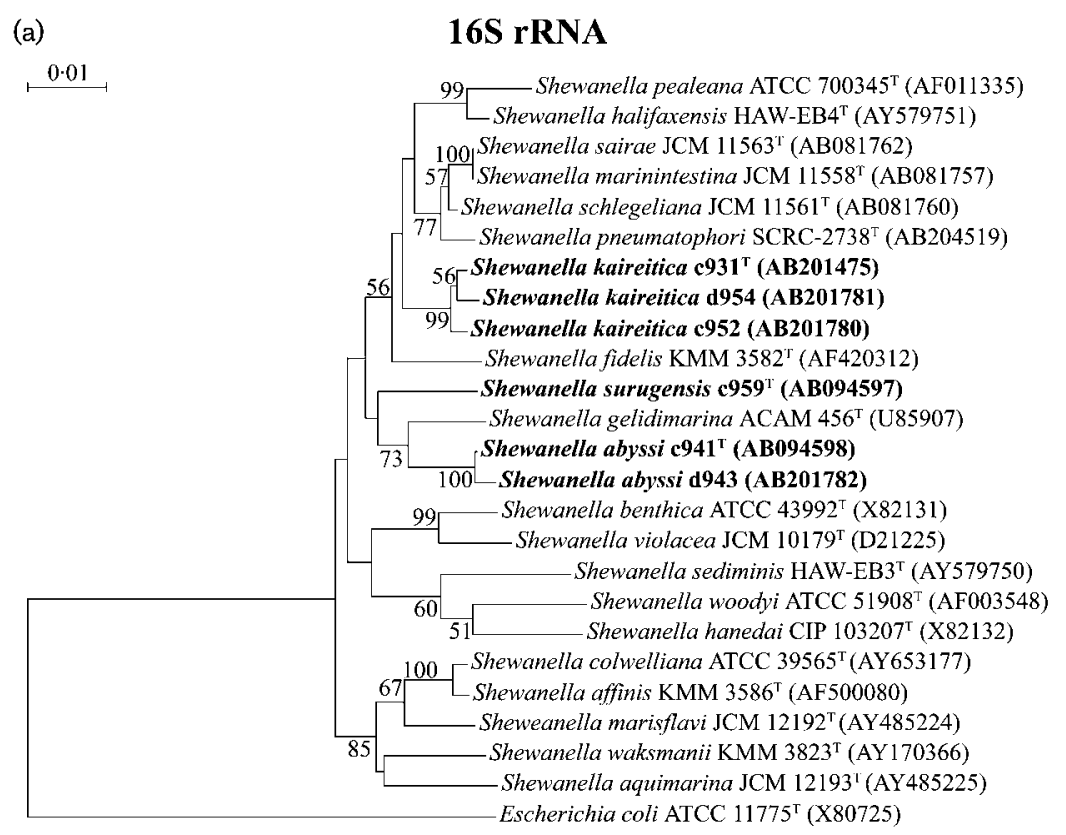

(b)

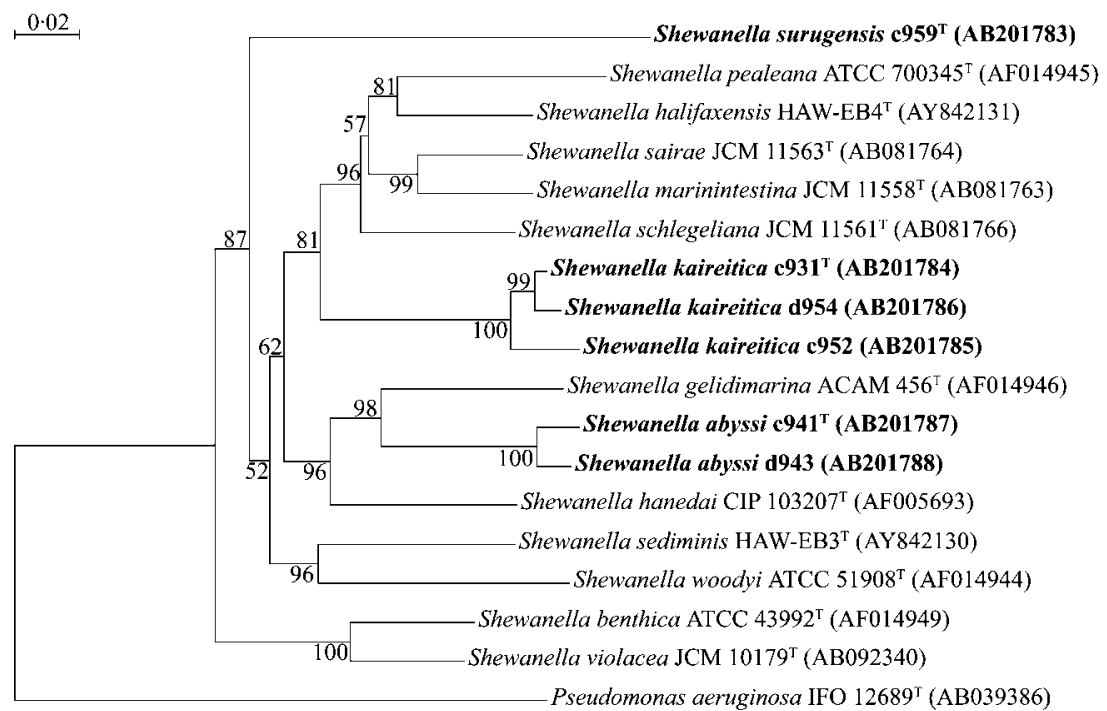

Fig. 1. Phylogenetic trees, constructed using the neighbour-joining method and based on 16S rRNA (a) and gyrB (b) gene sequences, showing the relationships of isolated strains $\mathrm{c} 931^{\top}, \mathrm{c} 941^{\top}, \mathrm{d} 943, \mathrm{c} 952$, d954 and $c 959^{\top}$ within the genus Shewanella. Bootstrap values were calculated from multiple resamplings of the sequence dataset, which are the basis for multiple tree topologies. Bars, 0.01 (a) and 0.02 (b) nucleotide substitutions per site. (i.e. showing significantly less than $70 \%$ relatedness) according to the recommendations of Wayne et al. (1987). This, together with the other results shown in Table 1 and Fig. 1, suggests that the isolated strains represent three novel species of the genus Shewanella.

The whole-cell fatty acid compositions of strains $c 931^{\mathrm{T}}$, $\mathrm{c} 941^{\mathrm{T}}$ and $\mathrm{c} 959^{\mathrm{T}}$ and the reference strains are shown in Table 3. The major fatty acids were as follows: strain $\mathrm{c} 931^{\mathrm{T}}$, iso- $\mathrm{C}_{15: 0}$ (isopentadecanoic acid), $\mathrm{C}_{16: 0}$ (hexadecanoic acid) and $\mathrm{C}_{16: 1}$ (hexadecenoic acid); strain $c 941^{\mathrm{T}}$, iso$\mathrm{C}_{13: 0}$ (isotridecanoic acid) and $\mathrm{C}_{16: 1}$; strain c959 $9^{\mathrm{T}}$, iso- $\mathrm{C}_{15: 0}$ and $\mathrm{C}_{16: 1}$. For each of the strains, the fatty acid profile showed low levels of similarity to those of the reference strains. For example, strain $\mathrm{c} 931^{\mathrm{T}}$ contained relatively large amounts of iso- $\mathrm{C}_{15: 0}$ and $\mathrm{C}_{16: 0}$ and small amounts of $\mathrm{C}_{20: 5} \omega 3$ (eicosapentaenoic acid), strain $\mathrm{c} 941^{\mathrm{T}}$ contained large amounts of iso- $\mathrm{C}_{13: 0}$ and $\mathrm{C}_{15: 0}$ (pentadecanoic acid) and small amounts of $\mathrm{C}_{16: 0}$ and strain $c 959^{\mathrm{T}}$ contained large amounts of $\mathrm{C}_{16: 1}$ and did not contain $\mathrm{C}_{20: 5} \mathrm{\omega} 3$.

Lowering of temperature has a physical effect on the fluidity of membrane lipids. As the growth temperature is lowered, biological membranes undergo a reversible change from a fluid, disordered state to a non-fluid, ordered state (Hazel \& Williams, 1990). The most common adaptive change observed among deep-sea bacteria involves the incorporation of increased proportions of unsaturated fatty acids into 
Table 1. Differential characteristics of Shewanella species

Taxa: 1, Shewanella kaireitica sp. nov. (strains c931 ${ }^{\mathrm{T}}$, c952 and d954); 2, Shewanella abyssi sp. nov. (strains c941 ${ }^{\mathrm{T}}$ and $\mathrm{d} 943$ ); 3 , Shewanella surugensis sp. nov. (strain $\mathrm{c} 959^{\mathrm{T}}$ ); 4, S. marinintestina; 5, S. schlegeliana; 6, S. sairae; 7, S. pealeana; 8, S. gelidimarina; 9, Shewanella fidelis; 10, S. violacea; 11, S. benthica. Cells of all species are Gram-negative rods that are motile by means of single polar flagella. The following tests were positive for all species: catalase activity, hydrolysis of gelatin and reduction of nitrate to nitrite. The following tests were negative for all species: hydrolysis of starch, production of indole and utilization of D-lactose. V, Variable depending on strain; ND, no data available. Data for reference species are from Satomi et al. (2003), Leonardo et al. (1999), Bowman et al. (1997), Ivanova et al. (2003) and Nogi et al. (1998), except where indicated otherwise.

\begin{tabular}{|c|c|c|c|c|c|c|c|c|c|c|c|}
\hline Characteristic & 1 & 2 & 3 & 4 & 5 & 6 & 7 & 8 & 9 & 10 & 11 \\
\hline Optimum growth temperature $\left({ }^{\circ} \mathrm{C}\right)$ & $24-25$ & $10-14$ & 13 & $20-25$ & $20-25$ & $20-25$ & 25 & $15-17$ & $20-25$ & 8 & 4 \\
\hline \multicolumn{12}{|l|}{ Growth at/in: } \\
\hline $30{ }^{\circ} \mathrm{C}$ & - & - & - & + & + & - & + & - & + & - & - \\
\hline $0 \% \mathrm{NaCl}$ & - & - & - & - & + & - & - & - & - & - & - \\
\hline $7 \% \mathrm{NaCl}$ & $\mathrm{V}$ & - & - & - & - & - & $+^{*}$ & $+^{*}$ & + & - & - \\
\hline \multicolumn{12}{|l|}{ Ubiquinone $(\%) \dagger$} \\
\hline Q-7 & $70-80$ & $65-70$ & 5 & Major & Major & Major & 70 & 75 & ND & 30 & 70 \\
\hline Q-8 & $20-30$ & $35-30$ & 95 & Major & Major & Major & 30 & 25 & ND & 70 & 30 \\
\hline Oxidase & + & + & - & + & + & + & + & + & + & + & + \\
\hline Lipase (tri-n-butyrin) & + & + & + & ND & $\mathrm{ND}$ & $\mathrm{ND}$ & $+^{*}$ & $+^{*}$ & ND & $+^{*}$ & - \\
\hline Chitinase & + & - & - & - & - & - & - & + & - & $\mathrm{ND}$ & + \\
\hline Urease & - & - & - & - & + & - & - & - & ND & $\mathrm{ND}$ & ND \\
\hline DNase & + & + & + & + & + & $+^{*}$ & - & + & + & $\mathrm{ND}$ & ND \\
\hline Tween 80 hydrolysis & + & - & + & + & - & + & - & + & $\mathrm{v}$ & $\mathrm{ND}$ & ND \\
\hline ONPG test & + & + & - & + & + & - & + & $+^{*}$ & ND & + & + \\
\hline Production of $\mathrm{H}_{2} \mathrm{~S}$ & + & + & - & + & + & + & + & + & + & - & + \\
\hline Nitrite reduced & + & + & - & $+^{*}$ & $+^{*}$ & $+^{*}$ & $+^{*}$ & $+^{*}$ & ND & $+^{*}$ & $+^{*}$ \\
\hline \multicolumn{12}{|l|}{ Acid from: } \\
\hline Cellobiose & + & $\mathrm{V}$ & - & - & - & - & $-*$ & - & - & + & + \\
\hline D-Fructose & + & - & + & - & - & - & - & - & - & - & - \\
\hline D-Galactose & + & - & - & - & - & - & + & - & - & + & - \\
\hline D-Glucose & + & - & + & - & - & - & + & - & + & + & + \\
\hline Glycerol & - & - & + & - & - & - & - & $-^{\star}$ & - & - & - \\
\hline Maltose & + & - & - & - & - & - & + & - & ND & - & - \\
\hline D-Mannitol & - & - & - & - & - & - & - & - & ND & - & - \\
\hline D-Mannose & - & - & + & - & - & - & $-^{*}$ & - & - & - & - \\
\hline L-Rhamnose & - & - & - & - & - & - & $-^{*}$ & $-^{*}$ & ND & - & - \\
\hline D-Sorbitol & + & - & - & - & - & - & - & $-^{*}$ & ND & - & - \\
\hline Sucrose & - & - & + & - & - & - & + & - & - & - & - \\
\hline
\end{tabular}

${ }^{\star}$ Data from this study.

†Proportions not given for S. marinintestina, S. schlegeliana or S. sairae; Q-7 and Q-8 are listed as major components.

membrane phospholipids (Allen et al., 1999). The largely psychrophilic or piezophilic Shewanella strains produce eicosapentaenoic acid (Margesin \& Nogi, 2004). However, strain $\mathrm{c} 959^{\mathrm{T}}$, adapted to a deep-sea environment, contained large amounts of $\mathrm{C}_{16: 1}$.

On the basis of the phenotypic, genotypic and phylogenetic data, it is logical to conclude that the deep-sea isolates we studied are members of the genus Shewanella and that they represent three novel species within this genus. We propose the names Shewanella kaireitica sp. nov. (type strain $\mathrm{c} 931^{\mathrm{T}}$ ), Shewanella abyssi sp. nov. (type strain $\mathrm{c} 941^{\mathrm{T}}$ ) and Shewanella surugensis sp. nov. (type strain $\mathrm{c} 959^{\mathrm{T}}$ ).

\section{Description of Shewanella kaireitica sp. nov.}

Shewanella kaireitica (kai.rei'tic.a. N.L. n. Kairei a research vessel; L. fem. suff. -tica adjectival suffix meaning 'belonging to'; N.L. fem. adj. kaireitica belonging to the research vessel Kairei).

Cells are rod-shaped; cell width ranges from 0.8 to $1.0 \mu \mathrm{m}$ and cell length ranges from 2.5 to $3.0 \mu \mathrm{m}$. Cells are Gramnegative and motile by means of single, unsheathed, polar flagella. Colonies on marine agar 2216 are entire, smooth, semitranslucent and salmon-coloured; $2-4 \mathrm{~mm}$ in diameter after $1-2$ days incubation at $20^{\circ} \mathrm{C}$. The bacterium is 
Table 2. DNA-DNA reassociation between the isolated strains and closely related Shewanella species

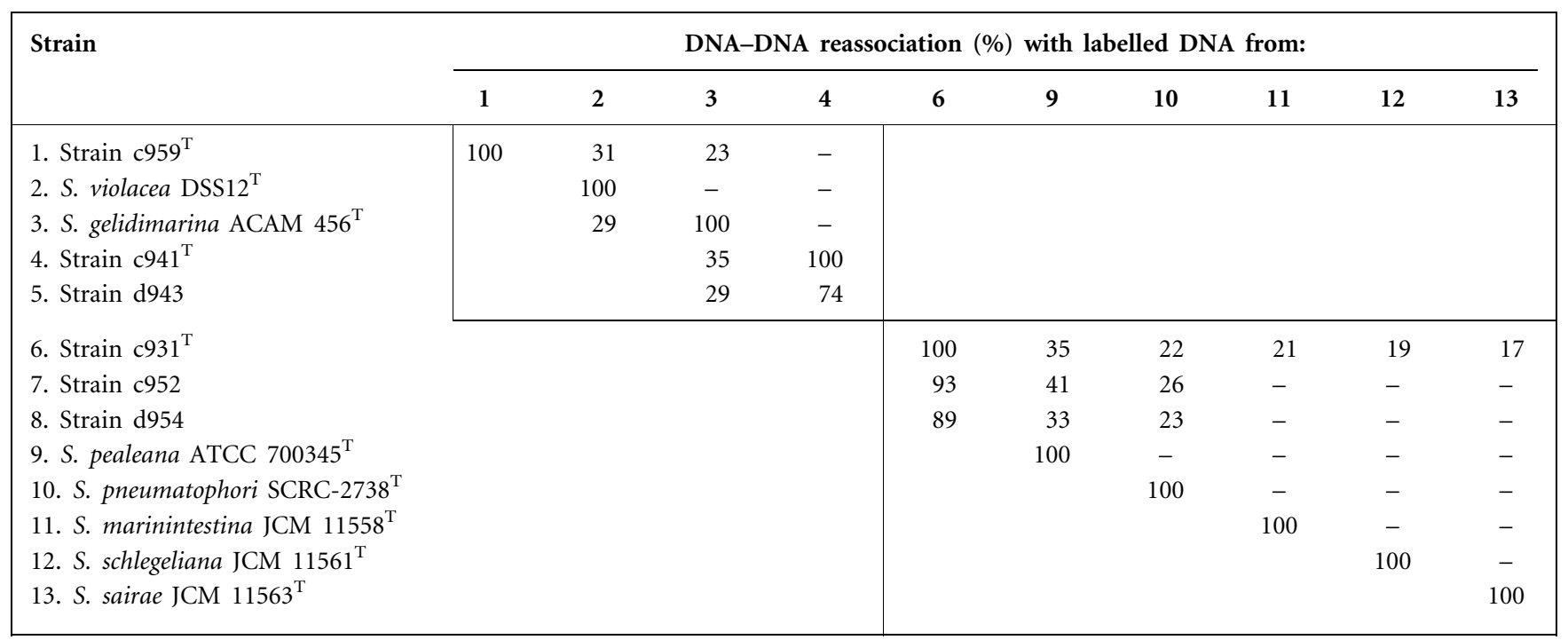

Table 3. Fatty acid compositions of the novel isolates and authentic Shewanella species

Taxa: 1, strain $\mathrm{c} 931^{\mathrm{T}} ; 2$, strain $\mathrm{c} 941^{\mathrm{T}} ; 3$, strain $\mathrm{c} 959^{\mathrm{T}} ; 4$, S. marinintestina JCM $11558^{\mathrm{T}} ; 5$, S. schlegeliana JCM $11561^{\mathrm{T}} ; 6$, S. sairae JCM $11563^{\mathrm{T}} ; 7$, S. pealeana ATCC $700345^{\mathrm{T}} ; 8$, S. gelidimarina ACAM $456^{\mathrm{T}}$; 9, S. fidelis KMM $3582^{\mathrm{T}}$; 10 , S. violacea DSS $12^{\mathrm{T}} ; 11$, S. benthica ATCC $43992^{\mathrm{T}}$. Values are percentages of total fatty acids. - Not detected; tr, trace $(<1 \%)$. Data for reference species are from Satomi et al. (2003), Leonardo et al. (1999), Bowman et al. (1997), Ivanova et al. (2003) and Kato \& Nogi (2001).

\begin{tabular}{|c|c|c|c|c|c|c|c|c|c|c|c|}
\hline Fatty acid & 1 & 2 & 3 & 4 & 5 & 6 & 7 & 8 & 9 & 10 & 11 \\
\hline $\mathrm{C}_{11: 0}$ & - & - & - & - & - & - & - & - & - & 3 & $\operatorname{tr}$ \\
\hline$C_{12: 0}$ & $2 \cdot 7$ & $2 \cdot 5$ & $1 \cdot 4$ & $0 \cdot 3$ & $1 \cdot 1$ & $0 \cdot 5$ & 4 & 1 & $1 \cdot 2$ & 4 & 2 \\
\hline $\mathrm{C}_{12: 0} 3-\mathrm{OH}$ & - & - & - & - & - & - & 3 & - & - & 1 & 1 \\
\hline iso- $\mathrm{C}_{13: 0}$ & $10 \cdot 3$ & $23 \cdot 1$ & $15 \cdot 3$ & $2 \cdot 8$ & $2 \cdot 8$ & $3 \cdot 4$ & 8 & 16 & $10 \cdot 7$ & 7 & 5 \\
\hline $\begin{array}{c}\text { iso- } \mathrm{C}_{13: 0} \\
3-\mathrm{OH}\end{array}$ & $2 \cdot 1$ & $4 \cdot 1$ & $3 \cdot 5$ & - & - & - & 5 & - & - & 8 & 5 \\
\hline $\mathrm{C}_{13: 0}$ & - & $1 \cdot 4$ & - & - & - & $1 \cdot 9$ & $\operatorname{tr}$ & 1 & $1 \cdot 5$ & $\operatorname{tr}$ & - \\
\hline iso- $\mathrm{C}_{14: 0}$ & - & - & - & - & - & - & $\operatorname{tr}$ & 1 & $0 \cdot 4$ & - & $\operatorname{tr}$ \\
\hline $\mathrm{C}_{14: 0}$ & $3 \cdot 4$ & $3 \cdot 9$ & $1 \cdot 1$ & $4 \cdot 4$ & $4 \cdot 2$ & $5 \cdot 0$ & 4 & 4 & $2 \cdot 3$ & 5 & 14 \\
\hline $\mathrm{C}_{14: 0} 3-\mathrm{OH}$ & - & - & - & - & - & - & 1 & - & - & - & - \\
\hline $\mathrm{C}_{14: 1}$ & - & - & - & - & - & - & - & 1 & $0 \cdot 2$ & 1 & - \\
\hline iso- $\mathrm{C}_{15: 0}$ & $21 \cdot 1$ & $9 \cdot 5$ & $18 \cdot 1$ & $9 \cdot 2$ & $6 \cdot 4$ & $14 \cdot 0$ & 12 & 8 & $22 \cdot 3$ & 13 & 11 \\
\hline anteiso- $C_{15: 0}$ & $\operatorname{tr}$ & $\operatorname{tr}$ & 1.9 & $0 \cdot 1$ & $0 \cdot 7$ & $0 \cdot 2$ & - & - & $0 \cdot 4$ & - & - \\
\hline $\mathrm{C}_{15: 0}$ & $1 \cdot 4$ & $11 \cdot 2$ & - & $0 \cdot 6$ & $0 \cdot 1$ & $0 \cdot 3$ & 1 & 7 & $8 \cdot 7$ & 6 & - \\
\hline $\mathrm{C}_{15: 1}$ & - & - & - & - & - & - & - & 3 & $1 \cdot 7$ & - & - \\
\hline $\mathrm{C}_{16: 0}$ & $21 \cdot 8$ & $10 \cdot 5$ & $8 \cdot 0$ & $22 \cdot 1$ & $22 \cdot 7$ & $18 \cdot 1$ & 20 & 6 & $12 \cdot 9$ & 14 & 14 \\
\hline $\mathrm{C}_{16: 1}$ & $26 \cdot 4$ & $19 \cdot 6$ & $48 \cdot 5$ & $26 \cdot 1$ & $26 \cdot 1$ & $28 \cdot 1$ & 19 & 27 & $20 \cdot 0$ & 16 & 31 \\
\hline iso- $\mathrm{C}_{17: 0}$ & - & - & - & - & - & - & 2 & $\operatorname{tr}$ & $0 \cdot 6$ & - & - \\
\hline iso- $\mathrm{C}_{17: 1}$ & - & - & - & - & - & - & - & - & $0 \cdot 3$ & - & - \\
\hline $\mathrm{C}_{17: 0}$ & - & $1 \cdot 4$ & - & $0 \cdot 6$ & - & $0 \cdot 1$ & 2 & 1 & $1 \cdot 5$ & 1 & $\operatorname{tr}$ \\
\hline $\mathrm{C}_{17: 1}$ & $\operatorname{tr}$ & $2 \cdot 5$ & - & $1 \cdot 0$ & $0 \cdot 5$ & $0 \cdot 8$ & 1 & 5 & $8 \cdot 2$ & 2 & $\operatorname{tr}$ \\
\hline $\mathrm{C}_{18: 0}$ & - & - & - & $3 \cdot 1$ & $1 \cdot 2$ & $1 \cdot 0$ & 2 & $\operatorname{tr}$ & $0 \cdot 3$ & - & - \\
\hline $\mathrm{C}_{18: 1}$ & $8 \cdot 9$ & $1 \cdot 2$ & $2 \cdot 2$ & $9 \cdot 0$ & $9 \cdot 8$ & $9 \cdot 8$ & 6 & 1 & $6 \cdot 0$ & 4 & 2 \\
\hline $\mathrm{C}_{20: 5} \omega 3$ & $1 \cdot 9$ & $9 \cdot 1$ & - & $17 \cdot 5$ & $18 \cdot 6$ & $15 \cdot 2$ & 11 & 16 & - & 14 & 16 \\
\hline
\end{tabular}

psychrotolerant. Exhibits optimal growth at $\mathrm{NaCl}$ concentrations of approximately 3-5\%; able to grow at $7 \% \mathrm{NaCl}$ (with the exception of strain d954). No growth occurs in the absence of $\mathrm{NaCl}$. Optimal temperature for growth is $24-25^{\circ} \mathrm{C}$. No growth at temperatures above $30^{\circ} \mathrm{C}$. Facultatively anaerobic chemo-organotroph, having both respiratory and fermentative types of metabolism. Catalase and cytochrome oxidase tests are positive. $\mathrm{H}_{2} \mathrm{~S}$ is produced. Nitrate is reduced to $\mathrm{N}_{2}$. Acid is formed oxidatively from cellobiose, D-fructose, D-galactose, D-glucose, maltose and D-sorbitol. No acid is produced from L-arabinose, glycerol, myo-inositol, D-lactose, D-mannitol, D-mannose, D-raffinose, L-rhamnose, sucrose, D-trehalose or xylose. The $\mathrm{G}+\mathrm{C}$ content of the DNA is approximately $43.0 \mathrm{~mol} \%$. The major isoprenoid quinone is $\mathrm{Q}-7$. The predominant cellular fatty acids are iso- $\mathrm{C}_{13: 0}$, iso- $\mathrm{C}_{15: 0}, \mathrm{C}_{16: 0}$ and $\mathrm{C}_{16: 1}$.

The type strain, $\mathrm{c} 931^{\mathrm{T}}\left(=\mathrm{JCM} 11836^{\mathrm{T}}=\mathrm{DSM} 17170^{\mathrm{T}}\right)$, and strains c952 and d954 were isolated from deep-sea sediment in Suruga Bay, Japan.

\section{Description of Shewanella abyssi sp. nov.}

Shewanella abyssi (a.bys'si. N.L. gen. n. abyssi from the abyss).

Cells are rod-shaped; cell width ranges from $0 \cdot 8$ to $1 \cdot 0 \mu \mathrm{m}$ and cell length ranges from $2 \cdot 0$ to $2 \cdot 5 \mu \mathrm{m}$. Cells are Gramnegative and motile by means of single, unsheathed, polar flagella. Colonies on marine agar 2216 are entire, smooth, semitranslucent and salmon-coloured; 2-4 $\mathrm{mm}$ in diameter after 2-3 days incubation at $10{ }^{\circ} \mathrm{C}$. The bacterium is psychrotolerant. Optimal growth occurs at a $\mathrm{NaCl}$ concentrations of $3-5 \%$. No growth occurs in the absence of $\mathrm{NaCl}$. The optimal temperature for growth is $10^{\circ} \mathrm{C}$. No growth occurs at temperatures above $25^{\circ} \mathrm{C}$. Facultatively anaerobic chemo-organotroph, having both respiratory and fermentative types of metabolism. Catalase and cytochrome 
oxidase tests are positive. $\mathrm{H}_{2} \mathrm{~S}$ and indole are produced. Nitrate is reduced to nitrite; nitrite is reduced to $\mathrm{N}_{2}$. Acid is formed oxidatively from cellobiose. No acid is produced from L-arabinose, D-fructose, D-galactose, D-glucose, glycerol, myo-inositol, D-lactose, maltose, D-mannitol, D-mannose, D-raffinose, L-rhamnose, D-sorbitol, sucrose, D-trehalose or xylose. The $\mathrm{G}+\mathrm{C}$ content of the DNA is approximately $43 \cdot 5 \mathrm{~mol} \%$. The major isoprenoid quinones are Q-7 and Q-8. The predominant cellular fatty acids are iso- $\mathrm{C}_{13: 0}$, iso- $\mathrm{C}_{15: 0}, \mathrm{C}_{16: 0}$ and $\mathrm{C}_{16: 1}$.

The type strain, $\mathrm{c} 941^{\mathrm{T}}\left(=\mathrm{JCM} 13041^{\mathrm{T}}=\mathrm{DSM} 17171^{\mathrm{T}}\right)$, and strain d943 were isolated from deep-sea sediment in Suruga Bay, Japan.

\section{Description of Shewanella surugensis sp. nov.}

Shewanella surugensis (su.ru.gen'sis. N.L. fem. adj. surugensis pertaining to Suruga Bay, where the type strain was isolated).

Cells are rod-shaped; cell width ranges from 0.4 to $0.6 \mu \mathrm{m}$ and cell length ranges from $3 \cdot 2$ to $4 \cdot 0 \mu \mathrm{m}$. Cells are Gramnegative and motile by means of single, unsheathed, polar flagella. Colonies on marine agar 2216 are entire, smooth, semitranslucent and cream-coloured; $2-4 \mathrm{~mm}$ in diameter after 2-3 days incubation at $10^{\circ} \mathrm{C}$. The bacterium is psychrotolerant. Optimal growth occurs at an $\mathrm{NaCl}$ concentration of approximately $3 \%$. No growth occurs in the absence of $\mathrm{NaCl}$. The optimal temperature for growth is $13{ }^{\circ} \mathrm{C}$. No growth occurs at temperatures above $25^{\circ} \mathrm{C}$. Facultatively anaerobic chemo-organotroph, having both respiratory and fermentative types of metabolism. The catalase test is positive. The cytochrome oxidase test is negative. Does not produce $\mathrm{H}_{2} \mathrm{~S}$. Nitrate is reduced to nitrite. Acid is formed oxidatively from D-fructose, D-glucose, glycerol, D-mannose and sucrose. No acid is produced from L-arabinose, cellobiose, D-galactose, myo-inositol, D-lactose, maltose, D-mannitol, D-raffinose, L-rhamnose, D-sorbitol, D-trehalose or xylose. The $\mathrm{G}+\mathrm{C}$ content of the DNA is approximately $40 \cdot 0 \mathrm{~mol} \%$. The major isoprenoid quinone is Q-8. The predominant cellular fatty acids are iso- $\mathrm{C}_{13: 0}$, iso- $\mathrm{C}_{15: 0}$ and $\mathrm{C}_{16: 1}$.

The type strain, c959 ${ }^{\mathrm{T}}$ ( = JCM $11835^{\mathrm{T}}=\mathrm{DSM} 17177^{\mathrm{T}}$ ), was isolated from deep-sea sediment in Suruga Bay, Japan.

\section{Acknowledgements}

We are very grateful to the Kaiko operation team and the crew of the M/S Kairei for helping us to collect the deep-sea samples. We also thank Dr Kikue Hirota (AIST) for providing us with bacterial strains.

\section{References}

Allen, E. E., Facciotti, D. \& Bartlett, D. H. (1999). Monounsaturated but not polyunsaturated fatty acids are required for growth of the deep-sea bacterium Photobacterium profundum strain SS9 at low temperature and high pressure. Appl Environ Microbiol 65, 1710-1720.
Barrow, G. I. \& Feltham, R. K. A. (1993). Cowan and Steel's Manual for the Identification of Medical Bacteria, 3rd edn. New York: Cambridge University Press.

Baumann, L., Baumann, P., Mandel, M. \& Allen, R. D. (1972). Taxonomy of aerobic marine eubacteria. J Bacteriol 110, 402-429.

Bowman, J. P., McCammon, S. A., Nichols, D. S., Skerratt, J. H., Rea, S. M., Nichols, P. D. \& McMeekin, T. A. (1997). Shewanella gelidimarina sp. nov. and Shewanella frigidimarina sp. nov., novel Antarctic species with the ability to produce eicosapentaenoic acid $(20: 5 \omega 3)$ and grow anaerobically by dissimilatory $\mathrm{Fe}(\mathrm{III})$ reduction. Int J Syst Bacteriol 47, 1040-1047.

DeLong, E. F., Franks, D. G. \& Yayanos, A. A. (1997). Evolutionary relationships of cultivated psychrophilic and barophilic deep-sea bacteria. Appl Environ Microbiol 63, 2105-2108.

Ezaki, T., Hashimoto, Y. \& Yabuuchi, E. (1989). Fluorometric deoxyribonucleic acid-deoxyribonucleic acid hybridization in microdilution wells as an alternative to membrane filter hybridization in which radioisotopes are used to determine genetic relatedness among bacterial strains. Int J Syst Bacteriol 39, 224-229.

Gauthier, G., Gauthier, M. \& Christen, R. (1995). Phylogenetic analysis of the genera Alteromonas, Shewanella, and Moritella using genes coding for small-subunit rRNA sequences and division of the genus Alteromonas into two genera, Alteromonas (emended) and Pseudoalteromonas gen. nov., and proposal of twelve new species combinations. Int J Syst Bacteriol 45, 755-761.

Hazel, J. R. \& Williams, E. E. (1990). The role of alterations in membrane lipid composition in enabling physiological adaptation of organisms to their physical environment. Prog Lipid Res 29, 167-227.

Hirota, K., Nodasaka, Y., Orikasa, Y., Okuyama, H. \& Yumoto, I. (2005). Shewanella pneumatophori sp. nov., an eicosapentaenoic acid-producing marine bacterium isolated from the intestines of Pacific mackerel (Pneumatophorus japonicus). Int $J$ Syst Evol Microbiol 55, 2355-2359.

Hugh, R. \& Leifson, E. (1953). The taxonomic significance of fermentative versus oxidative metabolism of carbohydrates by various gram negative bacteria. J Bacteriol 66, 22-26.

Ivanova, E. P., Sawabe, T., Gorshkova, N. M., Svetashev, V. I., Mikhailov, V. V., Nicolau, D. V. \& Christen, R. (2001). Shewanella japonica sp. nov. Int J Syst Evol Microbiol 51, 1027-1033.

Ivanova, E. P., Sawabe, T., Hayashi, K., Gorshkova, N. M., Zhukova, N. V., Nedashkovskaya, O. I., Mikhailov, V. V., Nicolau, D. V. \& Christen, R. (2003). Shewanella fidelis sp. nov., isolated from sediments and sea water. Int J Syst Evol Microbiol 53, 577-582.

Ivanova, E. P., Nedashkovskaya, O. I., Sawabe, T., Zhukova, N. V., Frolova, G. M., Nicolau, D. V., Mikhailov, V. V. \& Bowman, J. P. (2004). Shewanella affinis sp. nov., isolated from marine invertebrates. Int J Syst Evol Microbiol 54, 1089-1093.

Kato, C. \& Nogi, Y. (2001). Correlation between phylogenetic structure and function: examples from deep-sea Shewanella. FEMS Microbiol Ecol 35, 223-230.

Kato, C., Li, L., Nogi, Y., Nakamura, Y., Tamaoka, J. \& Horikoshi, K. (1998). Extremely barophilic bacteria isolated from the Mariana Trench, Challenger Deep, at a depth of 11,000 meters. Appl Environ Microbiol 64, 1510-1513.

Kimura, M. (1980). A simple method for estimating evolutionary rates of base substitutions through comparative studies of nucleotide sequences. J Mol Evol 16, 111-120.

Komagata, K. \& Suzuki, K. (1987). Lipid and cell-wall analysis in bacterial systematics. Methods Microbiol 19, 161-207.

Leonardo, M. R., Moser, D. P., Barbieri, E., Branther, C. A., MacGregor, B. J., Paster, B. J., Stackebrandt, E. \& Nealson, K. H. (1999). Shewanella pealeana sp. nov., a member of the microbial 
community associated with the accessory nidamental gland of the squid Loligo pealei. Int J Syst Bacteriol 49, 1341-1351.

MacDonell, M. T. \& Colwell, R. R. (1985). Phylogeny of the Vibrionaceae, and recommendation for two new genera, Listonella and Shewanella. Syst Appl Microbiol 6, 171-182.

Makemson, J. C., Fulayfil, N. R., Landry, W., Van Ert, L. M., Wimpee, C. F., Widder, E. A. \& Case, J. F. (1997). Shewanella woodyi sp. nov., an exclusively respiratory luminous bacterium isolated from the Alboran Sea. Int J Syst Bacteriol 47, 1034-1039.

Margesin, R. \& Nogi, Y. (2004). Psychropiezophilic microorganisms. Cell Mol Biol 50, 429-436.

Myers, C. R. \& Nealson, K. H. (1988). Bacterial manganese reduction and growth with manganese oxide as the sole electron acceptor. Science 240, 1319-1321.

Nogi, Y., Kato, C. \& Horikoshi, K. (1998). Taxonomic studies of deep-sea barophilic Shewanella strains and description of Shewanella violacea sp. nov. Arch Microbiol 170, 331-338.

Saito, H. \& Miura, K. (1963). Preparation of transforming deoxyribonucleic acid by phenol treatment. Biochim Biophys Acta 72, 612-629.

Saitou, N. \& Nei, M. (1987). The neighbor-joining method: a new method for reconstructing phylogenetic trees. Mol Biol Evol 4, 406-425.

Satomi, M., Oikawa, H. \& Yano, Y. (2003). Shewanella marinintestina sp. nov., Shewanella schlegeliana sp. nov. and Shewanella sairae sp. nov., novel eicosapentaenoic-acid-producing marine bacteria isolated from sea-animal intestines. Int J Syst Evol Microbiol 53, 491-499.

Semple, K. M. \& Westlake, D. W. S. (1987). Characterization of iron reducing Alteromonas putrefaciens strains from oil field fluids. Can J Microbiol 35, 925-931.
Simidu, U., Kita-Tsukamoto, K., Yamasato, T. \& Yotsu, M. (1990). Taxonomy of four marine bacterial strains that produce tetrodotoxin. Int J Syst Bacteriol 40, 331-336.

Stackebrandt, E. \& Goebel, B. M. (1994). Taxonomic note: a place for DNA-DNA reassociation and 16S rRNA sequence analysis in the present species definition in bacteriology. Int J Syst Bacteriol 44, 846-849.

Stackebrandt, E., Frederiksen, W., Garrity, G. M. \& 10 other authors (2002). Report of the ad hoc committee for the re-evaluation of the species definition in bacteriology. Int J Syst Evol Microbiol 52, 1043-1047.

Tamaoka, J. \& Komagata, K. (1984). Determination of DNA base composition by reverse-phase high-performance liquid chromatography. FEMS Microbiol Lett 25, 125-128.

Thompson, J. D., Gibson, T. J., Plewniak, F., Jeanmougin, F. \& Higgins, D. G. (1997). The CLUSTAL_X windows interface: flexible strategies for multiple sequence alignment aided by quality analysis tools. Nucleic Acids Res 25, 4876-4882.

Venkateswaran, K., Moser, D. P., Dollhopf, M. E. \& 10 other authors (1999). Polyphasic taxonomy of the genus Shewanella and description of Shewanella oneidensis sp. nov. Int J Syst Bacteriol 49, 705-724.

Wayne, L. G., Brenner, D. J., Colwell, R. R. \& 9 other authors (1987). Report of the ad hoc committee on reconciliation of approaches of bacterial systematics. Int J Syst Bacteriol 37, 463-464.

Yamamoto, S. \& Harayama, S. (1995). PCR amplification and direct sequencing of gyrB genes with universal primers and their application to the detection and taxonomic analysis of Pseudomonas putida strains. Appl Environ Microbiol 61, 1104-1109. 